\title{
EFFECT OF LOW DOSE DROPERIDOL ON POSTOPERATIVE VOMITING IN CHILDREN
}

\author{
Lucida Rita, Mashallah Goodarzi and Frank Seleny
}

\begin{abstract}
This double blind study assessed the effect of low dose droperiodol $\left(0.005 \mathrm{mg} \cdot \mathrm{kg}^{-1}\right)$ on the incidence of postoperative vomiting in 200 children in ASA classification I and II, ranging from one to 15 years of age. The results showed that the dose of droperidol used in this study was very effective in reducing vomiting in children 11 to 15 years of age. The duration of stay in the post-anaesthetic care unit was not prolonged and no extrapyramidal symptoms related to the drug were observed.

In our opinion the administration of droperidol $0.005 \mathrm{mg} \cdot \mathrm{kg}^{-1}$ before the end of the operation will reduce the possibility of vomiting within 24 hours of operation in children in $11-15$ year age group who are expected to have a high incidence of postoperative vomiting.
\end{abstract}

Key Words: ANAEsThesia, Complications, vomiting; Vomiting, antiemetics, droperidol.

VOMITING IS A common postoperative complication, especially in children. Sometimes it may be severe enough to warrant an intravenous infusion of fluid to prevent dehydration. If the surgery is done on an outpatient basis, vomiting may prevent the child from being taken home the same day.

There are many factors that influence vomiting in the postoperative period, according to the study by Purkis.'

Age: Children and adolescents have a higher incidence of vomiting as compared to adults.

Sex: Incidence of vomiting is equal in children up to 11 years of age, then females tend to vomit more than males.

Obesity: Obese patients tend to vomit more than thin patients.

Motion sickness: The occurence of postoperative vomiting is greater in children with a history of motion sickness.

Preoperative medication: There is a greater incidence of postoperative vomiting in patients given narcotics than in those given barbiturates or phenothiazines.

Induction agents: Vomiting is reduced in patients given thiopentone for induction.

Lucida Rita, M.D., Attending Anesthesiologist; Mashallah Goodarzi, M.D., Attending Anesthesiologist; Frank Seleny, M.D., F.R.C.P.(C), Head, Department of Anaesthesia, Children's Memorial Hospital, Northwestern University Medical School, Chicago, Illinois, U.S.A.

Reprint requests to: Dr. Lucida Rita, Department of Anaesthesia, Children's Memorial Hospital, 2300 Children's Plaza, Chicago, Illinois, 60611 U.S.A.

Canad. Anaesth. Soc. J., vol. 28, no. 3, May 1981
Anaesthetic agents: The kind of anaesthetic agent and duration of anaesthesia influence the incidence of postoperative vomiting.

Tracheal tubes: Patients who have tracheal intubation have a lower incidence of postoperative vomiting.

Type of surgery: Intra-abdominal procedures are associated with a greater incidence of postoperative vomiting than extra-abdominal procedures.

Several studies in adults have shown that droperidol is a powerful antiemetic. ${ }^{2,3}$ Shelley and Brown ${ }^{4}$ gave very low doses of droperidol (total dose $0.25 \mathrm{mg}$ ) intravenously at the time of induction to adults admitted for outpatient gynaecological operations. They found a statistically significant reduction in the incidence of vomiting in the postoperative period.

This study was undertaken to determine if a low dose $\left(0.005 \mathrm{mg} \cdot \mathrm{kg}^{-1}\right)$ of droperidol (comparable to the dosage used by Shelley and Brown) would be effective in preventing postoperative vomiting in children. Only inpatients were chosen for the study because of their availability for a 24 hour observation period.

\section{METHOD}

A double blind study was undertaken in 200 inpatient children ranging in ages from 1 to 15 years, ASA I \& II, undergoing orthopedic operations. Choosing this type of patient excluded the possibility of postoperative vomiting due to surgical causes. The children were divided into two 
groups, randomly selected. One group received placebo (saline), the other group received droperidol $0.005 \mathrm{mg} \cdot \mathrm{kg}^{-1}$ intravenously about one hour before the end of the operation.

All the children were given pentazocine $1.0 \mathrm{mg} \cdot \mathrm{kg}^{-1}$ and atropine $0.03 \mathrm{mg} \cdot \mathrm{kg}^{-1}$ intramus. cularly 45-60 minutes before the induction of anaesthesia. All the children had an inhalation induction with halothane, nitrous oxide and oxygen. This method of induction was decided upon in order to have uniformity in the study and to eliminate another variable, since thiopentone seems to influence the incidence of vomiting.

Anaesthesia was maintained with halothane, nitrous oxide and oxygen. All children had tracheal intubation. Again, this was done for uniformity of study so that another factor (no intubation) would not cloud the results. The children were observed for vomiting for a period of 24 hours postoperatively. Vomiting was defined as an active effort by the patients, whether there was expulsion of stomach contents or not. Children who received morphine or meperidine postoperatively for pain were eliminated from the study, since these agents would represent another variable.

In the post-anaesthetic care unit (PACU) one of the anaesthetists participating in the study observed the children and noted the length of stay. On the ward, the children were followed up by one of the anaesthetists participating in the study. He or she also reviewed the nurse's reports on the chart and talked to the parents.

Data were analyzed using chi-square analysis and Yate's correction for continuity was applied. $P<0.05$ was considered significant.

\section{Results}

The incidence of vomiting for 24 hours after operation in the 200 children studied were divided into different age groups as shown in Table I.

Children ranging in age from one to five years in the placebo group exhibited a higher incidence of vomiting ( 31.5 per cent) compared to the droperidol group (17.9 per cent). However, this was not statistically significant $\left(X^{2}=1.9 ; p<\right.$ 0.15 ). In children six to ten years of age, the placebo group showed a 48.2 per cent incidence of vomiting. The droperidol group was 28.4 per cent. Again, this was not statistically significant $\left(\mathrm{X}^{2}=0.6 ; \mathrm{p}<0.15\right)$. In children 11 to 15 years of age the incidence of vomiting in the placebo group was 54.5 per cent and 26.6 per cent in the droperidol group. This was statistically significant $\left(X^{2}=7.2 p<.007\right)$. There was no statistical difference in the mean anaesthetic time and mean recovery time between the placebo and droperidol groups at the different ages.

Anaesthetic time was measured from the start of induction of anaesthesia until the patient arrived in the PACU. Recovery time was measured from admission to PACU until the patient was discharged to the ward. The patients were observed for 24 hours starting from the time they entered PACU.

The overall incidence of vomiting in the 200 children studied is shown in Table II. The placebo group had a greater incidence of vomiting, 34 per cent in comparison to 25 per cent in the droperidol group. However, this was not statistically significant $\left(\mathrm{X}^{2}=1.9 ; \mathrm{p}<0.2\right)$. Also, thete was no significant statistical difference in the mean anaesthetic time and mean recovery time between two groups.

\section{Discussion}

Postoperative vomiting is a very unpleasant experience for children. Purkis ${ }^{\prime}$ showed that children and adolescents have the highest incidence of vomiting. We found that the younger children had a lower incidence of vomiting in the placebo group and that the occurrence of vomiting increased with approach of puberty (Table I). Smessaer $t^{5}$ found that the occurrence of vomiting is equal in both sexes in children. However, in adults, females tend to vomit more than males. We did not correlate sex to the incidence of vomiting in our study. The incidence of postoperative vomiting is between 30 per cent and 68 per cent of all patients. ${ }^{6}$ Our study showed an overall incidence of 34 per cent in the placebo group which is in the lower part of this range.

All the children in this study received pentazocine-atropine premedication, which may have an influence on vomiting. Dundee ${ }^{7}$ demonstrated that when narcotics were added to atropine as preoperative medication, the incidence of vomiting was increased. Leigh and Belton ${ }^{8}$ believe that a pharmacological peparation for children reduces the emotional trauma of anaesthesia and surgery and that this outweighs the disadvantages. Our previous stud $y^{9}$ also showed that there was a high incidence of stormy induction of anaesthesia and restlessness in the PACU in patients that were not premedicated.

Gold ${ }^{10}$ showed that the incidence of vomiting was less with thiopentone induction than with 
TABLE I

Total Number of Patients, Mean anaesthetic Time, Recovery Time, Percentage Vomiting and P-Value from Chi Square Analysis in Different AGE Groups

\begin{tabular}{|c|c|c|c|c|}
\hline & $\begin{array}{c}\text { Total } \\
\text { No. of } \\
\text { Patients }\end{array}$ & $\begin{array}{c}\text { Mean } \\
\text { Anaesthetic } \\
\text { Time (min.) }\end{array}$ & $\begin{array}{c}\text { Mean } \\
\text { Recovery } \\
\text { Time (min.) }\end{array}$ & $\begin{array}{l}\text { Per Cent } \\
\text { Vomiting }\end{array}$ \\
\hline \multicolumn{5}{|l|}{$1-5$ Years } \\
\hline Placebo & 38 & 144.8 & 77.6 & 31.5 \\
\hline Droperidol & 39 & 136.02 & 75 & $\begin{array}{c}17.9 \\
p<0.15\end{array}$ \\
\hline \multicolumn{5}{|l|}{ 6-10 Years } \\
\hline Placebo & 92 & 130.4 & 72.9 & 48.2 \\
\hline Droperidol & 26 & 136.5 & 80.2 & $\begin{array}{c}38.4 \\
p<0.15\end{array}$ \\
\hline \multicolumn{5}{|l|}{$11-15$ Years } \\
\hline Placebo & 33 & 153.03 & 83.7 & 54.5 \\
\hline Droperidol & 35 & 150.7 & 82.8 & $\begin{array}{c}26.6 \\
p<0.007^{*}\end{array}$ \\
\hline
\end{tabular}

${ }^{*} \mathrm{p}<0.05$ highly significant.

TABLE II

Total Number of Patients, Mean Anaesthetic Time, Recovery Time, Percentage Vomiting and P-Value from Chi Square Analysis of All ages

\begin{tabular}{lcccc}
\hline \hline & $\begin{array}{c}\text { Total } \\
\text { No. of } \\
\text { Patients }\end{array}$ & $\begin{array}{c}\text { Mean } \\
\text { Anaesthetic } \\
\text { Time (min.) }\end{array}$ & $\begin{array}{c}\text { Mean } \\
\text { Recovery } \\
\text { Time (min.) }\end{array}$ & $\begin{array}{c}\text { Recovery } \\
\text { Per Cent } \\
\text { Vomiting }\end{array}$ \\
\hline Placebo & 100 & 142.8 & 78.8 & 34 \\
Droperidol & 100 & 139.17 & 70.5 & $\begin{array}{c}25 \\
\mathrm{p}<0.15\end{array}$ \\
\hline
\end{tabular}

inhalation induction. In order to have uniformity in our study, all the children were induced with inhalation anaesthetics. We could then compare the incidence of vomiting in the different age groups under similar conditions.

The duration of anaesthesia also had an influence on the incidence of postoperative vomiting. ${ }^{7}$ Although the duration of anaesthesia was longer in our study for ages $11-15$ years, it was not statistically significant when compared to other age groups.

Droperidol is a powerful antiemetic. It is 800 times more potent than chlorpromazine on a weight for weight basis. Extrapyramidal symptoms have been reported in children who were given droperidol for premedication in the recommended dose range. " Children are believed to be more sensitive to the effects of the butyrophenone group of which droperidol is a member. None of our patients manifested extrapyramidal symptoms.
In conclusion, we found that droperidol in a dose of $0.005 \mathrm{mg} \cdot \mathrm{kg}^{-1}$ was very effective in children eleven to fifteen years of age in lowering the incidence of postoperative vomiting signifcantly. The duration of stay in the PACU was not significantly prolonged after the administration of the drug in this dose range. We also did not observe any extrapyramidal symptoms or hypotension. In our opinion the administration of droperidol $0.005 \mathrm{mg} \cdot \mathrm{kg}^{-1}$ before the end of the operation will reduce the possibility of vomiting within 24 hours of operation in children in the 11-15 year age group who are expected to have a high incidence of postoperative vomiting.

\section{REFERENCES}

I. Purkis, I.E. Factors that influence postoperative vomiting. Canad. Anaesth. Soc. J., /l: 335 (1964).

2. TORNETTA, F.J. A comparison of droperidol, diazepamand hydroxyzine hydrochloride as premedication. Anesth. Analg. 56: 496 (1977). 
3. Patton, C.M., Moon, M.R. \& Dannemiller, F.J. Prophylactic antiemetic effect of droperidol. Anesth. Analg. 53: 361 (1974).

4. Shelley, E.S. \& Brown, H.A. Antiemetic effect of ultra low dose droperidol. Abstracts \& Scientific Papers, ASA Annual Meeting 633 (1978).

5. Smessaert, A., Schehr, C.A \& Artusio, J.F. Nausea and vomiting in the immediate postanesthetic period. JAMA 170: 2072 (1959).

6. WinNing, T.J., Brock-UtNe, J.G. \& Downing, J.W. Nausea and vomiting after anesthesia and minor surgery. Anesth. Analg. 56: 674 (1977).

7. Dundee, G.W., Nicholl, R.M. \& Moore, J.
Studies of drugs given before anesthesia III, A method for the studying of their effects on postoperative vomiting and nausea. Brit J. Anesth. 34: 527 (1962).

8. Leigh, M.D. \& Belton, M.K. Premedication in infants and children. Anesthesiology 7:611 (1946).

9. Rita, L. \& Seleny, F.L. Pediatric outpatient anesthesia. Anesthesiology Review 1: 9 (1974).

10. Gold, M.I. Postanaesthetic vomiting in the recovery room. Brit. J. Anaesth. 4I: 143 (1969).

11. Dupre, L.J. \& Stieglitz, P. Extrapyramidal syndrome after premedication with droperidol in children. Brit. J, Anaesth. 52: 831 (1980).

\section{RÉSUMÉ}

Ce travail évaluait l'effet d'une dose légère de dropéridol $\left(0.005 \mathrm{mg} \cdot \mathrm{kg}^{-1}\right)$ sur l'incidence des vomissements post-opératoires chez deux cents enfants âgés de 1 à 15 ans et de classse I et ll (classification de l'ASA). Le dropéridol à la dose utilisée, s'est avéré très efficace pour abaisser l'incidence des vomissements chez les enfants de 11 à 15 ans. La durée de séjour en salle de réveil n'était pas prolongée par cet agent et l'on n'a pas observé de symptômes extra-pyramidaux aux doses administrées. C'est donc notre opinion qu'une dose de $0.005 \mathrm{mg} \cdot \mathrm{kg}^{-1}$ de dropéridol administrée avant la fin d'une intervention réduit les vomissements au cours des premières 24 heures post-opératoires chez les enfants de 11 à 15 ans qui forment un groupe où l'on retrouve une haute incidence de vomissements postopératoires. 